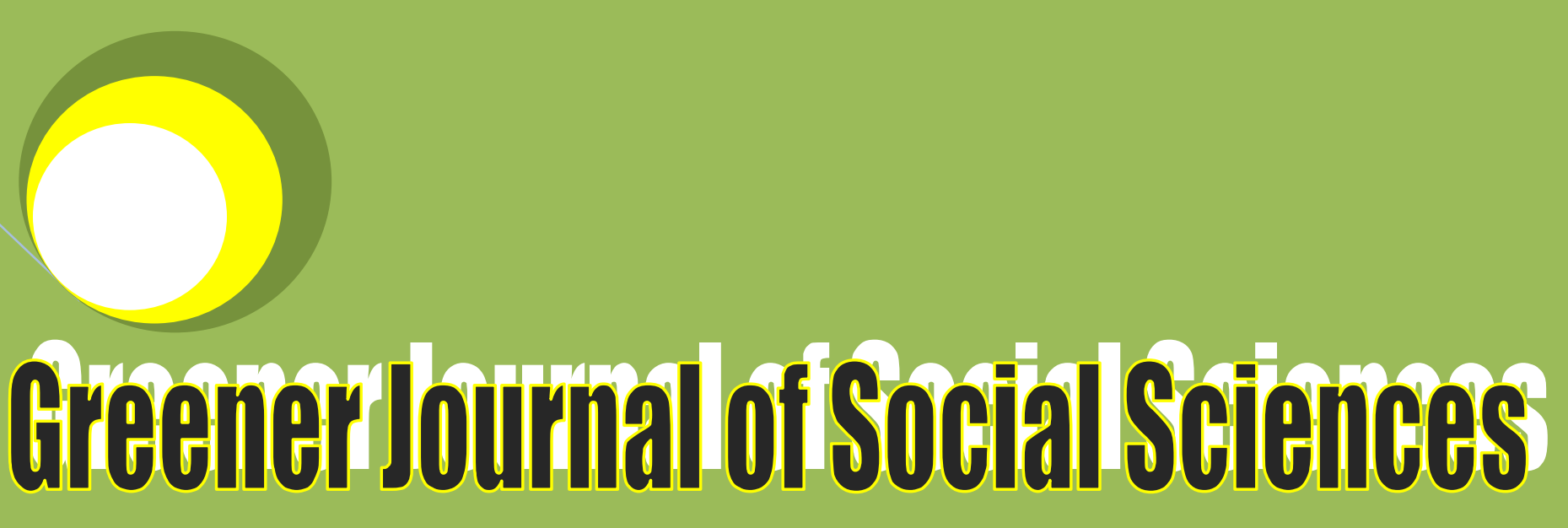

ISSN: 2276-7800

ICV: 5.99

Submitted: 08/06/2017

Accepted: 15/06/2017

Published: 28/06/2017

Subject Area of Article: Land Management

DOI: http://doi.org/10.15580/GJSS.2017.3.060817072

Customary Land Tenure

Disputes and Rural

Livelihoods in Zambia:

Case of Ufwenuka

Chiefdom in Southern

Province

By

Roy Alexander Chileshe

Niraj Jain

Remmy Chiselenga 


\title{
Customary Land Tenure Disputes and Rural Livelihoods in Zambia: Case of Ufwenuka Chiefdom in Southern Province
}

\section{Roy Alexander Chileshe ${ }^{\star 1}$, Niraj Jain ${ }^{2}$ and Remmy Chiselenga ${ }^{3}$}

\author{
${ }^{1}$ Department of Urban and Regional Planning, School of the Built Environment, Copperbelt University, P O Box \\ 21692, Kitwe, Zambia. \\ ${ }^{2}$ Department of Real Estate Studies, School of the Built Environment, Copperbelt University, PO Box 21692, Kitwe, \\ Zambia. \\ ${ }^{3}$ Graduate student, School of Graduate Studies, Dag HammerskjÖid Institute for Peace Studies Copperbelt \\ University, P O Box 21692, Kitwe, Zambia. \\ ${ }^{2}$ __jain_zm @yahoo. co.uk; Tel: +260-955-834545, \\ 3rchiselenga@ financebank.co.zm; Tel: +260-977-571079 \\ *Corresponding Author's Email: chilesher@ cbu.ac. zm; Tel: +260-977-971963
}

\begin{abstract}
This paper explores customary land disputes and their implications on livelihoods among the Tonga tribe in Southern Province of Zambia. Empirical data was acquired from a cluster of three small village communities located in Ufwenuka Chiefdom of Monze District. Data was collected through household questionnaires, informant's interviews, and focus group discussions. Respondents included village elders, village headmen and heads of households. The research shows that customary land disputes are relatively low in the village communities and when they occur they are mostly about competing interest for arable land and natural resources. Important livelihood implications of the disputes include: growing landholding insecurity; reduced access to natural resources; disruption of agriculture land use; and social tension within households, clans and the community; and loss of trust in traditional leaders. The study concludes that traditional institutions are central in determining access, use and control of land and natural resources in rural livelihoods and land dispute settlement. Consequently, strengthening traditional land administration institutions operating in the customary lands of Zambia is critical for local livelihoods.
\end{abstract}

Keywords: Land, customary land tenure, land disputes, rural livelihoods, Zambia.

\section{INTRODUCTION}

Land disputes and contestations in customary tenure jurisdictions of Africa have in recent years seen a rise in concern over people's livelihoods (Peters, 2004; Peters \& Kambewa, 2007; German et al, 2011; Young \& Sing'Oei, 2011; Paaga, 2013). Here a livelihood is understood to comprise people, their capabilities and their means of living, including food, income and assets (Chambers \& Conway 1991). Customary land tenure is defined as a bundle of rights in land founded on customs or practices which have been passed-on through generations. The use and disposal of customary land rights are based on the understanding that such rights are accepted as lawful by the community where the rules governing the acquisition and transfer of these rights are usually clearly and generally understood and accepted, even if they are not documented (Jowitt, 2004; Paaga, 2013).

Studies (see for instance Shackleton et al 2007; IFAD, 2012; Kalaba et al 2013) have shown that for rural households in Africa, land is a place of settlement providing opportunities for crop farming, grazing domestic animals, or collecting fire-wood or medicines and other natural resources of great value, such as water, and various other wild products. Thus, the importance of secure access to land and reduction of poverty for these households is seen from this backdrop (Toulmin \& Quan, 2000). However, customary land tenure contestations have been documented to be widespread amongst residents of villages and migrants, traditional authorities and individuals or village communities, family or clan elders and the young and between men and women and sometimes between state institutions and village communities (Nyambara 2001; Peters 2004; Richards 2005; ZLA \& ILC 2005; Peters \& Kambewa 2007; Wehrmaan 2008; Young \& Sing'Oei, 2011; Paaga 2013). 
In much of rural Africa, land governed under customary land tenure continues to be an important part of land management (Paaga, 2013). For example, out of Zambia's area of about $752614 \mathrm{~km}^{2}$, about $90 \%$ of it is held under customary tenure (Chileshe \& Shamaoma, 2011). Furthermore, about sixty-one percent (61\%) of Zambia's $15,000,000$ population (Achoki T, et.al., 2017) resides in rural areas with a population density standing at 17.3 persons per square kilometer (Republic of Zambia 2010). However, the government has since 1995 put in place market-based land tenure reform legislation (Republic of Zambia, 1995). This law among other things provides for the conversion of customary tenure to statutory tenure, however Brown (2003) has argued that this change in the law and other socio-economic changes in the country are often a source of controversy and disputes over customary land holding. Given this background, this study explores communal land disputes in rural Zambia and their implications on rural household livelihoods by investigating: land acquisition methods; the prevalence of land conflicts in village communities; the nature of land conflicts; and customary land conflict settlement approaches.

\section{Theory}

Up to the 1990s the neo-classical property rights model was used as the basis of land reform in most countries of sub-Saharan Africa (Place and Hazel 1994). Its popularity was because it was believed to promote land tenure security and consequently less land disputes, investment in land, economic development, and sustainable use of land (Williamson et al., 2010). This theory was however questioned and re-examined by many scholars in respect to customary land tenure reform in the sub Saharan Africa. When put to test it was found that land reform programs in Africa based on the model did not yield the expected results and had instead in most cases worsened land disputes and social inequalities (Attwood 1990). Scholars and development experts have since acknowledged the dynamic nature of African customary land systems. This is referred to as the 'Evolutionary Theory of Land Rights'. The central thesis of this theory is that customary land rights, under the impulse of market forces, are capable of autonomous evolution towards private property rights in land, individualisation and formalisation (Platteau, 2000; Cotula, 2007). This research paper's argument acknowledges a changing customary land tenure in which traditional leaders are grappling with resultant land disputes and compromised household livelihoods.

\section{MATERIALS AND METHODS}

\section{Study area}

The study area is located in the Southern Province, one of the ten provinces of Zambia. The province covers an area of $85,500 \mathrm{Km}^{2}$. The population of the province as captured during the 2010 Census of Population and Housing was $1,589,926$ and grew at an average rate of 2.8 percent per annum during the inter-censal period of 2000-2010 with a population density of 18.6 persons per square kilometre (Republic of Zambia, 2010). From the total population, 75.3\% live in rural areas whilst $24.7 \%$ live in urban areas of the province. The incidence of poverty was reported at $67.9 \%$ in 2010 (UNDP, 2013). The province is in a region receiving the lowest rainfall in the country with mean annual rain ranging from $650 \mathrm{~mm}$ to $800 \mathrm{~mm}$. The rain fall is irregular and unreliable. The altitude within the province rises from approximately 400m to 1400m (Republic of Zambia and Federal Republic of Germany, 2007).

\section{Research site}

The research site consisting of three villages namely Maanya, Himaamba, and Chinungwee located in Chief Ufwenuka's chiefdom were purposively selected. These are a cluster of villages on customary land sharing boundaries, inhabited by people governed by the same traditional chief, and speak the same language Chitonga. Before data collection could start, close collaboration was established with village headmen and village elders.

The research design used was mainly interpretative and in-depth inquiry complemented by a small sample questionnaire and focus group discussions. Qualitative data was collected through un-structured personal interviews and focus group discussions of purposively selected village community members including: village headmen; village elders; and heads of households. The structured questionnaire was specifically targeted at heads of households. Triangulation of data through conversations with various respondents in the village communities was a very important aspect of the research process. In addition, some data was also collected through secondary sources. The fieldwork was carried out during the month of June 2016. 


\section{Data collection and analysis}

The three villages had an estimated 245 households with a total population of about 1500 . The number of households was relatively small thus it was decided to interview about half of the total number of households which was 123 households. Households interviewed were selected in such a way that each household in the village community had an equal probability of inclusion in the sample. Thus, during the structured questionnaire survey every second household was selected, starting with the first one encountered. The number of households interviewed for each village was determined as a percentage of the total. The percentage was used as a basis upon which the targeted 123 was selected in each village and is shown in Table 1. For a number of reasons including refusals, only 115 respondents were interviewed. A Tonga speaking graduate student competent in the Tonga language widely spoken at the study site was trained and used to administer the questionnaire. Subsequent analysis of data involved transcribing, segmenting and coding of notes from unstructured interviews and focus group discussions and generation of frequency tables from the structured questionnaires.

Table 1: Selection of sample per village

\begin{tabular}{|l|c|c|c|}
\hline Village & $\begin{array}{c}\text { No. of } \\
\text { households }\end{array}$ & $\%$ & $\begin{array}{c}\text { Number of households } \\
\text { selected }\end{array}$ \\
\hline Maanya & 98 & 40 & 49 \\
\hline Himaamba & 68 & 28 & 34 \\
\hline Chinungwee & 79 & 32 & 39 \\
\hline Total & $\mathbf{2 4 5}$ & $\mathbf{1 0 0}$ & $\mathbf{1 2 3}$ \\
\hline
\end{tabular}

Source: Fieldwork, June 2016

\section{RESULTS AND DISCUSSION}

\section{Demographic Characteristics and Livelihoods}

In the three villages, the average household size was five members. Out of the one hundred and fifteen (115) heads of household respondents $79.1 \%$ were male and married and $20.9 \%$ were female with the following marital status: $9.6 \%$ were divorced and $11.3 \%$ were widows. The youngest head of household was 22 years and the oldest was 73 years and the mean age for the household heads was 45 years. The 115 household heads, interviewed were educated as follows: $77.4 \%$ had primary school education, $9.6 \%$ had secondary school education and $13 \%$ reported having no formal education.

Household members in the study site engage in multiple livelihood strategies. Table 2 shows a frequency distribution of engagement in livelihood activities. The main livelihood strategy in the study site is based on a mix of agro-pastoral farming. Almost all households (98\%) are involved in crop production. Most of the village residents $(80 \%)$ are subsistence farmers of staple grain (maize, millet and sorghum) and vegetables, with only a little surplus food to sell for cash. For the fewer well to do farmers crop production consists primarily of production of cash crops through ox-drawn plough cultivation, in particular hybrid maize. Cow manure and modern chemical fertilisers are used to improve soil fertility.

Some people (18\%) benefit from the government Fertiliser Support Programme (FISP). A relatively large number of village residents (77\%) indicated that they raise chickens, goats and cattle. They are good herdsmen with considerable knowledge of cattle breeding and pastures. These livestock contribute to their household diet but cattle in particular are mainly a source of wealth and are also used in settling marriage bride-wealth. Another important livelihood strategy in which $69 \%$ of households are involved is gathering and processing of various natural resources (fire wood, medicinal herbs, wild vegetables, and thatch grass) from the village commons and individual farms. Other livelihood strategies include trading (sale of repackaged groceries and beer brewing) and crafts (e.g. brick making and house building). In sum to a very large extent the village economy is basically agrarian predominated by subsistence farming. 
Table 2: Main Livelihood activities

\begin{tabular}{|l|l|r|l|}
\hline Livelihood category & Livelihood activity/ sources & No. & $\%$ \\
\hline Agriculture & Crop production & 113 & 98 \\
\hline & Livestock rearing & 89 & 77 \\
\hline Natural resource gathering and \\
processing & $\begin{array}{l}\text { Collecting wild plant and animal } \\
\text { resources }\end{array}$ & 79 & 69 \\
\hline Trading & Sale of repackaged Groceries & 14 & 12 \\
\hline & Beer brewing & 10 & 9 \\
\hline Crafts & & 8 & 7 \\
\hline & Brick making & 9 & 8 \\
\hline State loans & House building & 21 & 18 \\
\hline
\end{tabular}

Note: The question required respondents to make multiple responses for economically active household members.

Source: Fieldwork, June 2016

\section{Land tenure}

The holding of land under customary tenure in Zambia is recognised by the current law which provides that:

... every piece of land in a customary area which immediately before the commencement of this Act was vested in or held by any person under customary tenure shall continue to be so held and recognized...

(Republic of Zambia 1995, section 7 (1))

The case study villages are located on customary land and all residents in theory have the right to acquire customary land upon which they can construct their livelihood and the chief, headmen and village elders to a large extent administer and control acquisition and use of land. Apart from the right to cultivate the land acquired, village residents also have the customary right to exploit other natural resources within the village territory. It is a customary responsibility of the traditional leaders to provide information to land seekers on current existing rights in land in their village territories. This role of traditional leaders is meant to reduce the possibility of land conflicts in villages. The customary land holder is also under the law, free to convert his landholding from customary to statutory tenure. This is supported by the current land law in Section 8 subsection 1 and 2 as follows:

Any person who holds land under customary tenure may convert it into a leasehold tenure not exceeding ninety-nine years on application, in the manner prescribed.... The conversion of rights from a customary tenure to a leasehold tenure shall have effect only after the approval of the chief and the local authorities in whose area the land to be converted is situated (Republic of Zambia 1995).

In this group of villages, the extent to which land is regarded as a valuable asset worth registering is illustrated in Table 3 which shows that $4.3 \%$ held land on statutory land tenure and $6.1 \%$ are at different stages of conversion of customary tenure to statutory title. Although these figures are relatively low it is an emerging reality that some people living in customary tenure jurisdictions would rather hold land on statutory tenure. However, in practice this provision of the law is not easy for an ordinary villager to achieve. A headman observed that: 
Table 3: Land holding according to tenure

\begin{tabular}{|l|r|r|}
\hline Tenure Category & No. & $\%$ \\
\hline Customary & 103 & 89.6 \\
\hline Customary/Processing title & 7 & 6.1 \\
\hline Statutory & 5 & 4.3 \\
\hline Total & $\mathbf{1 1 5}$ & $\mathbf{1 0 0}$ \\
\hline
\end{tabular}

Source: Fieldwork, June 2016

The village elders and I get some requests from village residents to covert tenure so that they can have papers for the land they cultivate. They first come to me for support before making the request to the Chief. But I'm not keen to support such requests anymore because they are a source of problems for all of us in the village. Mistakes were made in the past were such permission were granted by the Chief. Some people just became impossible to live with. There were always trespass issues where none existed before. People argued about harvest of fire-wood, wild fruit and vegetables! The most annoying issue was arrogance and disrespect to village elders of those who had acquired government papers! Some people here behave as though they have papers even when they have failed to complete the processing of government papers because it is expensive and the process is lengthy. So now the village residents are not keen to listen to requests of permission for individuals to acquire government papers for land because it comes with disputes and contestations and is disruptive of village life. But if the Chief so wishes he may approve! (Interview June, 2016)

\section{Land acquisition methods}

Land acquisition in the study site is based on the customary land tenure principle that all village residents are entitled to land for their personal or household use. Studies done earlier among the Tonga showed that in the past when land was plentiful access to land by individuals living in the village was based on individual direct acquisition through cut and burn farming system. An individual needing land simply went out and cleared virgin land of his choice (White 1959; Colson, 1963, Mvunga 1982). This is not possible today in the study site as there is a scarcity of fertile arable land and consequently most arable land is repeatedly under cultivation and almost all land in the village territories has a history of ownership rights. Because of scarcity of arable land village headmen and family elders have since assumed tight control over land acquisition in the village territories. They do so through chairing family inheritance meetings, acknowledging gifts of land among relatives and friends, and approval of land sales within their village territories. Headmen's authority in these matters is embedded in traditional respect of 'elders' as stewards of land and village life. Even in cases where a land user intends to leave the village an effort is made to sell the land, or gift it to a relative. Cases of abandoned arable land are thus rare and village elders and headmen as administrators of land in the village would know about such cases and would quickly take charge and re-allocate the land (interview with headman). Heads of households were asked to indicate how they acquired their building site and main agriculture field which they were currently cultivating. Table 4 shows a summary of results.

Table 4: Arable land acquisition methods

\begin{tabular}{|l|r|r|}
\hline \multicolumn{1}{|c|}{ Method } & No. & $\%$ \\
\hline Allocation by headman & 8 & 7 \\
\hline Inheritance & 64 & 55.6 \\
\hline Gift & 34 & 29.6 \\
\hline Buying & 9 & 7.8 \\
\hline Total & $\mathbf{1 1 5}$ & $\mathbf{1 0 0}$ \\
\hline \hline
\end{tabular}

Source: Fieldwork, June 2016 
The most commonly used method for acquiring land was through inheritance which accounted for $55.6 \%$ of the responses. A village elder had this to say:

All the people here are very aware of the general shortage of fertile arable land and the difficulty in getting land for cropping outside the close family relations. Some large portions of land in this area have been abandoned after continuous ploughing, soils have become so poor and people have rendered them useless for purposes of ploughing for cropping. We now have to share the limited fertile land that we have with our children who are making a start in life. My two sons for instance plough with me, which is also good because I'm getting older and when I'm gone I would like my sons to take over the farm (Interview, June 2016).

The second most used method of land acquisition is by gift (29.6\%). In some instances, parents and indeed other relatives give gifts of land to children or close relatives. It is uncommon for a gift of land to be given to a distant relative or friend because of scarcity of land. The extent to which land is regarded as a scarce and valuable asset is illustrated by cases of arable land acquisition for a cash consideration or buying which was recorded at 7.8 percent (see Table 5). Sales of land are a definite indicator of intensifying competition over land emerging in the case study villages. Local farmers who are financially well-off than others and are in need of expansion of their cropping activities are often the buyers of land. In some cases, these well-off farmers buy land to help settle their newly-wed sons. Those who sell land are usually in urgent need of cash but they would normally seek the approval of other extended family members and elders. However, the sales of customary land are not without difficulty. The seller needs to convince the elders that his family and other 'close relatives' have sufficient land to construct a reasonable livelihood. Otherwise sale of land to outsiders is in most cases a debatable issue and a source of tension and dispute within the family and may call for the headman's intervention to make a decision on the matter. There is no doubt that sale of land in the study site is subject to negotiation with immediate family, extended family, and sometimes the village community and its leaders and it is these processes that pose insecurity for prospective buyers. It is safe to conclude that sale and buying of land is not widely accepted in the study site but is a reality that cannot be ignored.

Table 5: Number of fields per household

\begin{tabular}{|l|r|r|}
\hline Number of fields owned Per household & No. of households & $\%$ \\
\hline $1-2$ & 73 & 63.4 \\
\hline $3-4$ & 37 & 32.2 \\
\hline $4-5$ & 5 & 4.4 \\
\hline Total & $\mathbf{1 1 5}$ & $\mathbf{1 0 0}$ \\
\hline
\end{tabular}

Source: Fieldwork, June 2016

The village community in the study site have for a long time been associated with commercial maize agriculture and have thus, stabilised in their land holding and can be said to be practicing sedentary improved farming. The majority $(63.4 \%)$ of village residents hold one or two fields and very few $(4.4 \%)$ own 4 to 5 fields. Through the years, population pressure in the study area has also contributed to competition between land requirements for cultivation and that for grazing cattle.

\section{Land disputes and nature of land disputes}

Land disputes in customary lands of Africa are reported to be wide spread. The current scarcity of arable land in the study site has resulted in competing interests in land and in some cases leading to land disputes among village residents. Land disputes at the study site were reported at $28.7 \%$, (Table 6 ) therefore they are not rare but cannot be said to be wide spread as other studies have shown in other customary areas of Africa (Peters \& Kambewa 2007; Wehrmaan 2008; Young \& Sing'Oei, 2011; Paaga 2013). A large number of respondents (71.3\%) were not involved in land disputes and the villagers in the study site can therefore be said to reasonably coexist in relative peace concerning land matters within their village communities. In a situation of dual land tenure, land scarcity and emerging commercial land-use, land disputes that occurred in the study site were usually about boundary encroachment, sale of land, natural resource use, land inheritance, and conversion of tenure (see Table 7). 
Table 6: Incidence of dispute over land

\begin{tabular}{|l|r|c|}
\hline \multicolumn{1}{|c|}{ Involved in land disputes } & No. & $\%$ \\
\hline Yes & 33 & 28.7 \\
\hline No & 82 & 71.3 \\
\hline Total & $\mathbf{1 1 5}$ & $\mathbf{1 0 0}$ \\
\hline
\end{tabular}

Source: Fieldwork, June 2016

Table 7: Nature of dispute over land

\begin{tabular}{|l|l|r|}
\hline \multicolumn{1}{|c|}{ Nature of dispute } & No. & \% \\
\hline Boundary encroachment & 8 & 7 \\
\hline Sale of land & 7 & 6.1 \\
\hline Natural resource use rights & 6 & 5.2 \\
\hline Inheritance & 5 & 8.7 \\
\hline Conversion of tenure & 2 & 1.7 \\
\hline No land disputes & 82 & 71.3 \\
\hline Total & 115 & 100 \\
\hline
\end{tabular}

Source: Fieldwork, June 2016

Within the study site the problem of boundary encroachment was recorded at $8 \%$. Boundary encroachment between neighbouring customary landholders, usually occur through systematic stealthy cultivation of each other's land. Even when land claims are made it is difficult to establish land encroachment in these cases because land boundaries are defined as general boundaries constituted by foot paths, anthills big trees and other natural features. Goodwill between neighbours is required to keep the peace but a family elder explained that:

...people are under pressure to cultivate more land for their food needs but large tracts of land have been degraded through continuous cultivation and overgrazing and so they resort to going beyond their known land boundaries every year and hoping their neighbour will not challenge them (Interview June 2016).

The focus group discussion revealed that this problem is also common between those holding land on customary tenure basis and those who have converted their tenure or are in the process of converting tenure to statutory tenure. While it is evident that almost all households in the study villages make their living out of cropping and harvesting of natural resources, some conversions of tenure have entailed carving land from the village commons and in this way impeding neighbouring households from expanding their crop fields or accessing key natural resource livelihoods resources. Land disputes usually arise after a farmer converts tenure and in the process establishes physical boundaries by clearing or erecting a fence around his farm. This triggers boundary disputes with neighbouring customary land holders who may not agree with the exact boundaries. Although government procedure on conversion of customary land to statutory tenure requires consultation of all stakeholders (Republic of Zambia, 1995), evidence from the study area shows that the practice does not usually result in consensus on boundaries. A farmer who is in the process of converting tenure and is growing maize as a cash-crop on customary land narrated how tension has developed between him and his neighbouring farmers:

I moved here from Lusaka when I retired from employment as a civil servant ten years ago and acquired twelve (12) hectare of land with the permission of the headman. Acquiring land those days was easy especially because I was born here. I'm in the process of acquiring government papers for 
my farm. As you can see I have built a brick house, store-rooms, a water borehole and a shed for my maize crop. But I have a problem with small-cultivators on the boarders of my farm. On several occasions I have been involved in land boundary disputes with neighbouring customary land holders who when they want to expand their fields encroach my farm boundaries. These people do not respect my farm boundaries because the title to my land is not finalised and so to make my boundaries visible I have cleared vegetation along my boundary lines. These people come from surrounding villages and encroach on my land and most of them work on my farm on piecework basis, tending my animals, ploughing, planting, weeding and harvesting crop. Now our relationship is stressed! (Interview June 2016)

Disputes in respect of sale of land usually revolve around whether customary land has submitted to land sales. Within the same village community are different views on the question of sale of land and this brings about challenges and contestations and disputes between people of different views on the matter. In some cases, people for different reasons want to relocate and as a consequence would like to dispose off the land they are currently farming or living on through a sale. Sometimes people would simply like to sell a portion of their land for a cash consideration to meet family needs. Such intentions are often met with objections from family members who do not agree with the idea of subjecting customary land to a sale. A young farmer explained his predicament and disappointment after his family elders blocked a sale of one of his fields:

I acquired land for a consideration in cash from a family whose relative had died from suspected witchcraft and wanted to relocate to another village. The land was sold cheap to me because the family of the deceased wanted to quickly leave the village and I wanted land to expand my field and took the opportunity. After five years I also wanted to sell the same land to a newcomer so that I could meet some cash needs of my family. My family elders have objected and explained that they were not happy to have me sell land to an outsider! The outsider heard about the objection from my family elders and has withdrawn his offer because he now has fears that he will not be at peace if he proceeds with the purchase of land. I feel unfairly impeded by my family elders; I have a right to dispose of self-acquired land especially because I also paid for the land (Interview June 2016).

Land disputes arising from sale of land may sometimes be attributed to village headmen who see opportunity to earn money while playing their role as village administrators and consequently get involved in fraudulent disposal of customary land to the financially powerful in the village. These are often men with influence and access to cash resources. In such cases land agreements are completed stealthily and objections of affected village residents are ignored or simply dismissed by a headman involved. Although the focus group discussion observed that such cases were very few, one farmer's case illuminates the alleged fraudulent disposal of customary fallow land by a headman:

One morning last year during the cultivation period I decided to go and plough a field which I had kept in fallow for two years to regain fertility. To my surprise a man who had recently settled in the village had started to plough my field. I carefully approached the man to understand why he had decided to plough land which did not belong to him. The man told me with confidence that the headman had allowed him to plough the land which in his view was abandoned. I lost my temper and a quarrel ensued between us. We were summoned by the headman for a hearing. After hearing what I had to say, the headman quickly rebuked me for not sharing my plans to fallow the land in question. The headman ruled that I had forfeited my land-use because of my careless attitude. Later my close relatives and friends whispered to me that the land was given away by the headman for a cash consideration! I had no proof but I stopped the ploughing by the new settler through threats. But I also have not taken up the land in fear of the headman and the land still remains fallow (Interview June 2016).

The worry here is the unclear way in which fallow land abruptly switched ownership under the facilitation of a headman without concern of existing land rights and thereby resulting in a land dispute and social tension. This case suggests that within this village context of relative land scarcity, some village headmen may have found ways in which land claims by the less powerful against the more well-off villagers are settled to the disadvantage of the vulnerable leading to loss of access to land and compromised livelihoods.

As earlier indicated land inheritance by individuals is currently the dominant method of land acquisition in the study site. However, the right to inherit land in the study site is not specific to which relative of the deceased should inherit. This complicates the issue on who should inherit amongst close relatives of the deceased and it often 
becomes an arena of struggle in the nuclear and extended family of the deceased. A farmer involved in an inheritance disagreement lamented:

I worked very hard with my father, mother and my wife to build our farm houses, stumping the land and applying manure with cow-dung, planting fruit trees and sugar cane. We ploughed large fields for the maize cash crop to earn more cash for our family. But my father died in 2014. After the funeral the family elders called a meeting at which my father's affairs were to be settled. The elders recognised my efforts to help my father develop the farm. I expected the elders to rule in my favour. But they ruled that my father also had two other young relatives who needed more land to cultivate and that these were also important matrilineal beneficiaries. So a decision was made to sub-divide the land which my father had left into three with the largest offered to me. In this way what was to be my land was taken away. What was my sweat for? I complained but no one heard me and so my relations with my elders are now poor - I don't trust them (Interview with famer, June 2016).

From the above case of land inheritance, we see evidence of some aspect of social consequence of cash cropping and farm development with the surviving son directing more weight to nuclear family inheritance by sons as opposed to customary matrilineal inheritance recognised by family elders and extended family. A compromise appears to have been the solution to this challenging problem in which the son is awarded a share of his late father's land and the rest awarded to other needy extended family members. But even this settlement is not acceptable to the son who directly invested his labour in the development of the farm.

\section{Settlement of land disputes}

The majority of disputes were settled by family elders and/or headman. Out of the 33 disputes reported in the villages only 1 was reported to have been taken to Court. There is no doubt that the customary arrangement of dispute settlement works well as the aggrieved person is required to first consult a respected family elder who then calls for a meeting or conversation with the disputants to find an agreeable settlement on the matter. It is only when this fails that the aggrieved can take recourse for the matter to be heard and settled by a headman. Otherwise a headman has the status and power to settle land disputes within his village territory and this is the dominant way of land dispute settlement in the study site as indicated in Table 8.

Table 8: Dispute settlement

\begin{tabular}{|l|l|l|}
\hline Dispute settlement through: & No. & $\%$ \\
\hline Village Headman & 17 & 14.8 \\
\hline Family elders & 14 & 12.2 \\
\hline Chief & 1 & 0.9 \\
\hline Local court & 1 & 0.9 \\
\hline No land conflict & 82 & 71.3 \\
\hline Total & $\mathbf{1 1 5}$ & $\mathbf{1 0 0}$ \\
\hline
\end{tabular}

Source: Fieldwork June 2016

Thus, taking disputes to the Chief is seen as a sign of stubbornness on the part of the disputants which may displease the headman because it usually makes him seem incompetent on governing his own village matters. The village community expects a competent headman to use customary institutions or rules and procedures to resolve land disputes. The formal court is perceived to be costly and unnecessary. A headman had this to say:

We headmen are the stewards of land in the villages. It is a great responsibility and sometimes very lonely! There is not much free land left out here except for grazing land and that we cannot give away for ploughing. Some newcomers even want to buy grazing land which belongs to everyone in the village. In some cases we are even accused of ruling in favour of close relatives but we do not do that lest we lose the respect of all the village residents. We are respected men because we are honest and we always want to dialogue with land disputants and reach a settlement that leads to healing and forgiveness and maintain our respect. We always strive to reach an amicable settlement between disputants. When we reach a settlement we encourage all involved to close the matter. It is embarrassing to take up the Chief's time just to present a matter that we can deal with locally (Interview June 2016). 
At the focus group discussion, the view that matters of land dispute between clan's men are better settled by elders within the village prevailed. It was agreed that it was the duty of elders to ensure that land disputes do not take away friendship and peace from brothers. The claimants should be allowed a chance to tell their story in which they can express their disappointment but insults should not be allowed. Even when one's land claim is valid the elders may plead with him for mutual agreement to assist the one whose land claim is weak but has greater need to use a portion of the land and in this way peace is expected to prevail. However, it was also pointed out that some men are extremely fierce when they are involved in land contestations. Although such men are feared they do not enjoy the respect of other villagers as they are considered arrogant (Focus group discussion June 2016).

\section{Land disputes and livelihoods}

In the study site the importance of access to land is crucial for all households because the village economy is fundamentally agrarian, predominated by subsistence farming and the majority of villagers also depend on access to natural resources within the village territory. Land is therefore an essential resource for the cultivation of the staple crop, it is the basis for generation of income through maize cash cropping and indeed a source of pasture for cattle. Thus, access to fertile arable land, within the village communities is important because it is a principal source of food, income and general wellbeing of households. Consequently, land disputes do compromise household food supply and other land-based livelihoods. Heads of households that reported having been involved in land disputes were requested to indicate the main way in which the dispute affected their livelihood (see Table 9).

Table 9: Land dispute implications on household livelihoods

\begin{tabular}{|l|l|l|}
\hline Land dispute effect & No. & $\%$ \\
\hline Tenure insecurity & 5 & 4.3 \\
\hline Household tension & 8 & 7 \\
\hline Disruption of land use & 11 & 9.6 \\
\hline Reduced access to natural resources & 9 & 7.8 \\
\hline No land dispute & 82 & 71.3 \\
\hline Total & $\mathbf{1 1 5}$ & $\mathbf{1 0 0}$ \\
\hline
\end{tabular}

Source: Field survey 2016

The majority of respondents indicated that disruption of land use was the main outcome from land disputes in which they were involved. This meant that important livelihood activities such as cultivation of food crops were disturbed until the dispute was settled. Other serious disputes resulted in reduced access to natural resources such as thatching grass, building poles, wild fruit and vegetables located on land which had been carved out from the village commons and a process of conversion of tenure is started without consensus on boundaries with the village community. The community continues to argue that village land is being alienated selfishly. In such cases the land owner converting tenure usually jealously police the boundaries of the land to prevent encroachment and trespass and disputes arise with the villagers attempting to harvest natural resources or expand crop fields. In this way the village community suffers reduced access to natural resources and consequently affecting their livelihoods. Both parties are insecure in their perceived land rights and this often results in tension and tension interferes with the necessary reciprocity livelihood relations which are necessary among village households.

\section{CONCLUSIONS}

The study has clearly shown that customary land in the study site is a fundamental livelihood resource upon which all the households in the village communities depend for the construction of various livelihoods including food production for subsistence, commercial cropping purposes, livestock pasture and various useful natural resources. At village level the headmen and village elders to a large extent administer and control acquisition and use of land based on their interpretation of local rules which are currently under pressure from changing land acquisition methods. Current trends and patterns in the study site suggest that access to land is often through inheritance, purchase, gifts and allocation with headmen having an advisory and supervisory role. However, the scarcity of fertile arable land to meet the demand for subsistence and commercial cropping; conversion of customary land tenure to statutory tenure; controversial customary land alienation by headmen and village elders have resulted in a number of 
land disputes though not widespread. Land disputes in the communities are often related to local competition among village households, with each household striving to gain access to adequate fertile arable land and natural resources. For now, dependence on local institutions in land dispute settlement is still largely predominant because, it is cheaper and reconciliatory. There is no doubt that there is a need for improvement in customary land administration in respect of: clarity of landholding boundaries; clarity in inheritance rules; consistence in settlement of land disputes by headmen and village elders; and conversion of tenure processes. If these areas of customary land administration are not improved, land disputes are bound to increase leading to compromised livelihoods of village residents.

\section{AUTHORS' CONTRIBUTIONS}

- Roy Alexander Chileshe and Niraj Jain were involved in the collection of secondary data, primary data and thereafter analysis.

- Remmy Chiselenga was involved in the collection and analysis of field data from Ufwenuka Chiefdom in Southern Province of Zambia.

- All authors were involved in the write-up of this article.

\section{REFERENCES}

Achoki T, Kinfu Y, Masiye F, Frederix GW, Hovels A, Leufkens HG, (2017). Health system productivity change in Zambia: A focus on the child health services. Journal of Public Health Policy, Vol 38, Issue 1, pp 88-104.

Adams M, Sibanda S and Turner S (2000). Land tenure reform and rural livelihoods in Southern Africa. In C. Toulmin and J. Quan (eds.) Evolving Land Rights, Policy and Tenure in Africa. London: Department for International Development, International Institute for Environment and Development and Natural Resources Institute: 135-149.

Amone C and Lakwo C (2014). Customary land ownership and underdevelopment in Northern Uganda. International Journal of Social Science and Humanities Research, Vol. 2, No.3, pp: 117-125.

Attwood D (1990). 'Land registration in Africa: The impact on agricultural production', World Development, vol. 18, no. 5, pp. 659-671.

Brown T (2003). Contestation, confusion and corruption: Market-based land reform and local politics in Zambia. Unpublished paper. Crewkerne: the IDL group.

Berry S (1993). No condition is permanent, the social dynamics of agrarian change in subsaharian Africa. The University of Wisconsin Press, Madison.

Chambers R and Conway GR (1991). Sustainable rural livelihoods: practical concepts for the $21^{\text {st }}$ Century. IDS Discussion paper 296.

Colson E (1963). Land rights and land use among the Valley Tonga of the Rhodesian Federation: The background to the Kariba Resettlement Programme. In D. Biebuyck (ed.), African Agrarian Systems. London: Oxford University Press.

Cotula L (ed.) (2007). Changes in "customary" land tenure systems in Africa. IIED/FAO, London/Rome.

Cousins B (1997). How do land rights become real? Formal and informal institutions in South Africa's Land Reform. IDS Bulletin (October): 59-68.

Delville PL (1999). Harmonising formal law and customary land rights in French-Speaking West Africa. IIED Paper No. 86, London.

de Soto H (2000). The Mystery of Capital: Why Capitalism Triumphs in the West and fails Everywhere Else. New York: Basic Books.

DFID (2007). Land: better access and secure rights for poor people. Department for International Development: London

German L, Schoneveld G and Mwangi E (2011) Contemporary processes of large-scale land acquisition by investors: case studies from sub-Saharan Africa. Occasional Paper 68. CIFOR, Bogor, Indonesia.

IFAD (2012). Land tenure security and poverty reduction. International Fund for Agricultural Development: Rome Jowitt A (2004). Indigenous land grievances, customary land disputes and restorative justice. Journal of South Pacific Law, Vol. 8 No. 2. http://www.paclii.org/journals/fJSPL/vol08no2 /8.shtml

Kalaba FK, Quinn CH and Dougill AJ (2013). Contribution of forest provisioning ecosystem services to rural livelihoods in the Miombo woodlands of Zambia. Population and Environment, Vol. 35 No. 2, p 159 -182.

Mvunga MP (1982). Land law and policy in Zambia. Gweru: Mambo Press. 
Mudenda MM (2006). The Challenges of Customary Land Tenure in Zambia. Paper presented at the XXIII FIG Congress Munich, theme: Shaping the Change, Germany, October 8-13, 2006

Nyambara PS (2001). The closing frontier: agrarian change, immigrants and the "squatter menace in Gokwe, 19801990s', Journal of Agrarian Change 1, 4: 534-49.

Paaga DT (2013). Customary land tenure and its implications for land disputes in Ghana: Cases from Wa, Wechau and Lambussie. International Journal of Humanities and Social Science, Vol. 3 No. 18 pp 263 -270

Paaga DT and Dandeebo G (2014). Assessing the appeal of traditional dispute resolution methods in land dispute management: Cases from the Upper West Region. Developing Country Studies, Vol 4, No. 11 pp 1-9

Peters P (2004). Inequality and social conflict over land in Africa. Journal of Agrarian Change, Vol, 3, no1/2, p306

Peters P E and Kambewa D (2007). Whose security? Deepening social conflict over 'customary' land in the shadow of land tenure reform in Malawi. The Journal of Modern African Studies, 45, pp 447-472 doi:10.1017/S0022278X07002704

Place F, Roth M and Hazel P (1994). Land tenure security and agricultural performance in Africa: Overview of Research Methodology. In Bruce, J. W. and Migot-Adholla, S. E. (eds.), Searching fort land tenure security in Africa. Kendal/Hunt Publishing Company.

Platteau JP (2000). 'Does Africa need land reform?', in C Toulmin and J Quan (eds.), Evolving land rights, policy and tenure in Africa, DFID/IIED/NRI, London.

Republic of Zambia and Federal Republic of Germany (2007). The Groundwater Resources of Southern Province, Zambia (Phase 1) Volume 1 - Technical Report. Republic of Zambia and Federal Republic of Germany Technical Co-operation, Project No. BMZ PN 2003.2024.2. Lusaka. Htpps://www.bgr.bund.de/EN/Themen/Wasser/Projekter/TZ. Accessed on $19^{\text {th }}$ August 2016.

Republic of Zambia (1995). The Lands Act, 1995. Lusaka: Government Printers.

Republic of Zambia (2010). 2010 Census of Population and Housing. Lusaka: Central Statistics Office

Richards P (2005). To fight or to farm? Agrarian dimensions of the Mano River conflicts (Liberia and Sierra Leone), African Affairs 104, 417: 571-90.

Shackleton CM, Shackleton SE, Buiten E, and Bird N (2007). The importance of dry woodlands and forests in rural livelihoods and poverty alleviation in South Africa. Forest Policy and Economics, 9(5), 558-577.

Toulmin C and Quan J (2000). Registering Customary Rights. In Toulmin, C and Quan, J. (eds.), Evolving land rights, policy and tenure in Africa. London: Department for International Development, International Institute for Environment and development and Natural Resources Institute: 207-228.

Toulmin C and Quan J (2000). Evolving land rights, tenure and policy in Sub-Saharan Africa. In Toulmin C and Quan $\mathrm{J}$ (eds.), Evolving land rights, policy and tenure in Africa. London: Department for International Development, International Institute for Environment and development and Natural Resources Institute: 1-29.

URI/ARLPI (2012). Mitigating land based conflicts in Northern Uganda. URI: San Francisco

UNDP (2013). Millennium Development Goals Provincial Profile Southern Province. UNDP: Lusaka.

USAID (2004). Land and Conflict: A tool kit for intervention. USAID, Washington

Wehrmann B (2008). Land conflicts: A practical guide to dealing with land disputes. Deutsche Gesellschaft für Technische Zusammenarbeit (GTZ), Eschborn, Germany

White CMN (1959). A survey of African land tenure in Northern Rhodesia. Journal of African Administration, 11(4) and 12(1).

Whitehead A and Tsikata D (2003). Policy discourses on women's land right in Sub-Saharan Africa. Journal of Agrarian Change, Vol, 3, no1/2, pp 67- 112.

World Bank (1989). Sub-Saharan Africa: from crisis to sustainable growth. World Bank, Washington, DC.

Young LA and Sing'Oei K (2011). Land, livelihoods and identities: Inter-community conflicts in East Africa. Minority Rights Group International, London

ZLA and ILC (2005). Communities' views on the land policy: draft land policy review consultation process in Zambia. Zambia Land Alliance, Lusaka

Cite this Article: Chileshe RA, Jain N and Chiselenga R (2017). Customary Land Tenure Disputes and Rural Livelihoods in Zambia: Case of Ufwenuka Chiefdom in Southern Province. Greener Journal of Social Sciences, 7(3): 022-033, http://doi.org/10.15580/GJSS.2017.3.060817072 